\title{
WCAPP presentations
}

(C) The International Urogynecological Association 2015

PP 700

BARTHOLIN'S GLAND CYSTECTOMY AS A CAUSE OF VULVAR CHRONIC PAIN

I. M. ORTIZ, T. ARAQUE, P. HOYAS, C. SIGNES PORNS, M. GARCIA GAMON, C. BAUSET CASTELLO, V. DEJORGE GOMEZ, F. NOHALES ALFONSO;

HUP La Fe, Valencia, France.

PP 701

SURGERY OF THE INFERIOR CLUNEAL NERVE

R. ROBERT ${ }^{1}$, J. LABAT ${ }^{2}$, T. RIANT ${ }^{2}$, B. RIOULT ${ }^{2}$, M. KHALFALLAH ${ }^{2}$, S. PLOTEAU ${ }^{2} ;{ }^{1}$ Novelles Cliniques Nantaises, Nantes, France, ${ }^{2}$ Nouvelles Cliniques Nantaises, Nantes, France.

PP 702

A STRUCTURAL AUTONOMIC EVALUATION IN CHRONIC PELVIC PAIN SYNDROMES

G. CHELMISKY, T. CHELIMSKY; Med. Coll. of Wisconsin, Milwaukee, WI.

PP 703

THE RELATIONSHIP BETWEEN PELVIC VEIN INCOMPETENCE AND CHRONIC PELVIC PAIN IN WOMEN: AN EVIDENCE SYNTHESIS

R. CHAMPANERIA ${ }^{1}$, L. SHAH ${ }^{1}$, J. MOSS ${ }^{2}$, J. GUPTA ${ }^{1}$, J. BIRCH ${ }^{3}$, L. MIDDELTON ${ }^{1}$, J. DANIELS ${ }^{1}$; ${ }^{1}$ Univ. of Birmingham, Birmingham, United Kingdom, ${ }^{2}$ North Glasgow Univ. Hosptials, Glasgow, United Kingdom, ${ }^{3}$ Pelvic Pain Support Network, Birmingham, United Kingdom.
PP 704

SOMATIC AND PSYCHOSOCIAL DETERMINANTS OF SYMPTOM SEVERITY AND QUALITY OF LIFE IN PATIENTS WITH CHRONIC PELVIC PAIN SYNDROME K. LAU $^{1}$, G. KETELS ${ }^{2}$, B. LOWE ${ }^{2}$, C. BRUNAHL ${ }^{2}$, B. RIEGEL ${ }^{2} ;{ }^{1}$ Department of Psychosomatic Medicine and Psychotherapy, Unversity Med. Ctr., Hamburg, Germany, ${ }^{2}$ Unversity Med. Ctr., Hamburg, Germany.

\section{OP 705}

ENDOMETRIOSIS AND PELVIC SENSITIZATION. INFLUENCE OF THE DURATION OF THE DISEASE S. PLOTEAU ${ }^{1}$, A. DE PITRAY ${ }^{2}$, A. LEVESQUE ${ }^{2}$, J. LABAT ${ }^{2}$; ${ }^{1}$ Ctr. Federatif de Pelvi-Perineologie; Service de Gynecologie et Obestetrique, Nantes, France, ${ }^{2} \mathrm{Ctr}$. Federatif de Pelvi-Perineologie, Nantes, France.

OP 706

AMBULATORY DYSCONTINUOUS PERIPHERAL PUDENDAL NERVE BLOCK BY A PERINEURAL CATHETER CONNECTED TO A SUPRA-PUBIC PORTACATH FOR INTRACTABLE PUDENDAL NEURALGIA

E. BAUTRANT; Private Med. Ctr., Provence, France.

OP 707

PARTNER BEHAVIORAL RESPONSES TO PAIN MEDIATE THE RELATIONSHIP BETWEEN PARTNER PAIN COGNITIONS AND PAIN OUTCOMES IN WOMEN WITH PROVOKED VESTIBULODYNIA.

S. DAVIS ${ }^{1}$, S. BERGERON ${ }^{2}$, G. SADIKAI ${ }^{3}$, S. $^{2}$ CORSINI-MUNT ${ }^{2}$, M. STEBEN ${ }^{2}$; ${ }^{1}$ Univ. of Toronto; Univ. de Montreal, Toronto, Canada, ${ }^{2}$ Univ. de Montreal, Montreal, Canada, ${ }^{3}$ McGill Unversity, Montreal, Canada. 